\title{
Legal basis for the use of educational technologies in the knowledge information space formation
}

\author{
Marina Alekseeva ${ }^{1, *}$, Inna Podroykina ${ }^{2,3}$, and Yulia Isakova $^{3}$ \\ ${ }^{1}$ Don State Technical University, 34403, Gagarina sq., 1, Rostov-on-Don, Russia \\ ${ }^{2}$ Rostov Branch of the Russian Customs Academy, 344002, Budennovsky ave., 20, Rostov-on-Don, \\ Russia \\ ${ }^{3}$ Don State Technical University, 34400, Gagarina sq, 1, Rostov-on-Don, Russia
}

\begin{abstract}
The aim of the study is to analyze the legal framework for the use and development of various educational technologies, including distance learning, e-learning, in the implementation of educational programs as measures for the formation of the information space of knowledge. The research methodology, based on objective facts and a logical-analytical tool of scientific knowledge, made it possible to understand the ways of obtaining new scientific knowledge, predetermined the main directions of research, ensured the comprehensiveness of obtaining information, and made it possible to systematize the knowledge gained. The article analyzes the legal framework governing the field of education. It was found that despite the development of information technologies, including in the field of education, there is no single developed terminological apparatus that would allow participants in the educational process to understand the content of such concepts as "learning and education in distance and electronic forms", as well as to distinguish between They noted that the amendments made in 2020 to the Law on Education, caused by the emergency situation related to the spread of the new coronavirus infection and the transition of educational institutions to distance learning, did not solve the indicated problem.
\end{abstract}

\section{Introduction}

One of the measures necessary for the formation of the information space of knowledge, established by the decree of the President of the Russian Federation of May 9, 2017 №203 (sub. "i" clause 26) on the development of the information society in the Russian Federation for 2017 - 2030, is the use of remote and e-learning.

The necessity and possibility of implementing this measure, in the words of the famous Russian educator and innovator G.K. Selevko, are conditioned by the fact that pedagogical technology in any of its manifestations is based on information, which is based on the technological process of learning [1], in addition, any pedagogical technology has one or

* Corresponding author: alekseeva80@yandex.ru 
another degree of interactivity, and some of them contain an interactive mode as a mandatory component [2].

Information technologies and distance learning are increasingly entering our lives, it is no coincidence that some researchers [3] devote their work to understanding blended learning, including at school, but in our opinion today it is more relevant to analyze the legal basis for the use and development of various educational technologies, including distance learning, e-learning, in the implementation of educational programs, in order to develop recommendations for further improving the regulatory framework governing this area.

\section{Research methodology and methods}

The work is based on such a method as system analysis, in addition, in order to more detailed and complete study of the topic, the authors relied on the formal legal method, as well as on the comparative legal method.

\section{Results}

In the literature, the concepts of "educational technologies" and "pedagogical technologies" are often not separated. Although, strictly speaking, the concept of "pedagogical technologies" implies the regulation of the process of achieving goals in the educational process, and the concept of "educational technologies" in this process to a greater extent reflects the organizational aspect of education. According to the main and most essential features of these technologies, their classification is also carried out.

For example, the work of G.K. Selevko "Modern educational technologies" (1998) contains a description of about 50 (within groups and subgroups of about 100) pedagogical technologies. In his other work "Encyclopedia of Educational Technologies" (2006), taking into account the modernization of the traditional education system, the author has already described about 500 educational technologies.

In both editions, the named author considers computer technologies as information learning technologies associated with the unique capabilities of modern computers and telecommunications.

However, in the first book, he only briefly characterizes computer technologies as "new information learning technologies" as part of pedagogical technologies based on the effectiveness of management and organization of the educational process, does not highlight the concept of educational Internet technologies and distance educational technologies, although he notes that the Internet is for learning completely unique opportunities, indicates that "the combination of computer training programs with a telecommunications network is a kind of distance learning (distance learning)".

In the second book by G.K. Selevko already considers distance learning and computer technologies as macro, and network and telecommunication technologies as metainteractive technologies as part of active teaching methods.

Among the information and communication educational technologies, he singles out the technology of using the Internet in the educational process, within the framework of which distance learning is separately considered, which can not only complement and significantly affect the entire education system.

The main component of the content of distance education, in his opinion, are: the technology of a student's work with information, and the main organizational technologies are a case, network and telecommunication educational technologies [1]. 
Highlighting distance forms of education, mention should be made of working with training courses via the Internet, the use of electronic means of communication between the teacher and the student, virtual laboratories, online updating of training courses.

External forms of presenting the content of education in distance learning are electronic textbooks, interactive websites and educational sites [2].

At present, in Russia, almost all educational organizations of higher, professional, secondary and additional education in one way or another implement educational technologies based on the "expansion" (updating of information content and functional capabilities) of their Internet sites, the use of electronic information and educational environment, development of online learning [4] and other modern digital technologies. Researchers pay special attention to the need for pedagogical support when taking various online courses as part of extracurricular independent work [5].

Many different educational organizations carry out e-learning and online learning in detail, use and develop virtual educational platforms and information services, educational materials in the public domain.

The use and development of educational technologies is impossible without appropriate information resources. With this in mind, among the means of teaching and upbringing, the Federal Law "On Education in the Russian Federation" identifies "printed and electronic educational and information resources" (clause 26 of article 2, part 3 of article 16).

In this case, electronic information resources are considered as a means of ensuring management in the field of education, in an educational organization and in the educational process. The basis of electronic educational resources is educational content. Electronic information resources in the field of education have a wide range of species.

It is important to note that, taking into account the concepts of analog and digital information, electronic educational resources are more a source of information for knowledge, and digital educational resources (online resources) are interactive in nature, play the role of tools in the process of receiving and transmitting knowledge.

With this in mind, online, mobile and network learning can be considered separately as a form (method of organizing) training and as a measure for the formation of the information space of knowledge.

The creation of conditions for the implementation of a modern and safe digital educational environment is considered as the basis for the development of the education sector in the Decree of the President of the Russian Federation dated 07.05.2018 No. 204 "On national goals and strategic objectives of the development of the Russian Federation for the period up to 2024".

The implementation of activities of the national project "Education" and the state program of the Russian Federation "Development of Education" is aimed at the active use and development of e-learning and distance educational technologies in educational activities.

Achievement of "digital maturity" in the field of education was established by Decree of the President of the Russian Federation of July 21, 2020 No. 474 as a target indicator characterizing the achievement of national goals by 2030 within the framework of the national idea of "Digital Transformation".

However, at the same time, a number of issues remain unresolved in the legal regulation of the issues under study, related to the legal definition of the categories "distance education" and "distance learning" actively used in science and law enforcement practice of educational law, the use of the definition of "e-learning" in all forms of implementation of educational law, as well as the legal term "distance learning technologies" in relation to the subordinate level of legal regulation in terms of the ratio and identification of forms of education and applied technologies. 
In the context of Russia's joining the Bologna process in 2003, the specified definitions were included in the conceptual and categorical apparatus [6], the result of this activity was the conclusion of intergovernmental agreements on cooperation in the field of higher education and its development on the basis of information and communication technologies [7]. the legal framework of interstate integration associations in the post-Soviet space on the need to take coordinated measures to form a unified field of education [8-9].

To the beginning of the implementation of the provisions of these agreements and recommendations on the development of the process of obtaining education in distance learning, Russian legislation did not contain norms regarding the designated categories, in science the concepts of "distance education" and "distance learning" did not have an unambiguous disclosure. Therefore, in order to legislatively consolidate the process under consideration, the concept of "distance learning technologies" was chosen.

In the Law of the Russian Federation "On Education" (1992), the competence of an educational institution in the implementation of the educational process was attributed to "the use and improvement of methods of the educational process and educational technologies, including distance learning technologies" and in relation to this it is determined that "distance educational technologies "are" educational technologies, implemented mainly with the use of information and telecommunication technologies with indirect (at a distance) or not completely mediated interaction between the student and the teacher."

The Order of the Ministry of Education and Science of Russia dated 06.05.2005 № 137 approved the Procedure for the use of distance learning technologies (now no longer valid), which established that an educational institution has the right to use distance learning technologies for all forms of education provided for by the legislation of the Russian Federation or when they are combined, when conducting various types of educational, laboratory and practical classes, practices (excluding industrial practice), monitoring, intermediate certification of students.

At the beginning of 2012, in the context of organizing the educational process in accordance with the new requirements, the rules for the use of distance and electronic forms of education were changed. In particular, the electronic form of education was defined as "the organization of the educational process using the information contained in databases and used in the implementation of educational programs and ensuring its processing of information technologies, technical means, as well as information and telecommunication networks that ensure the transmission of this information through communication lines. , interaction of participants in the educational process".

Understanding e-learning as an organization of the educational process made it possible to speak of it as an independent form of education, although e-learning is a form of learning, a way of organizing educational activities, the process of interaction between teachers and students, the process of transferring and assimilating knowledge.

The structural approach to the definition of the concept of "distance learning technologies" in the Law remained the same, however, fundamental changes were made to the content of the concept by Federal Law №11-FL dated February 28, 2012 (now invalidated): the words "using information and telecommunications technologies "were replaced by the words" with the use of information and telecommunication networks ", and the functional-target component of the concept" ... with indirect (at a distance) or not completely mediated interaction between the student and the pedagogical worker "in this regard received a more substantive consolidation - "... mediated (at a distance) interaction between students and teachers".

The analysis shows that the concepts of "e-learning" and "distance learning technologies" were enshrined in the Law of the Russian Federation "On Education" taking 
into account the provisions of the Model Law on Distance Learning in the CIS Member States (2011) [10]. And although during the incorporation they underwent certain changes, as we can see, it was not possible to completely avoid mistakes.

The concepts of "distance learning" [11] and "distance education" [12], defined in other recommendatory (model) acts of the CIS and EurAsEC, were not incorporated into the Law as having great obvious ambiguity in disclosure, inconsistency between themselves and other concepts under consideration.

The consolidation in the Law of the concepts of distance education and electronic (distance) learning as a means of developing virtual mobility was not ensured due to the specifics and difficulties of implementing the Bologna process in Russia.

The Federal Law "On Education in the Russian Federation" (2012) formally canceled the entire existing regulatory framework for the use and development of various educational technologies, including distance learning, e-learning, in the implementation of educational programs.

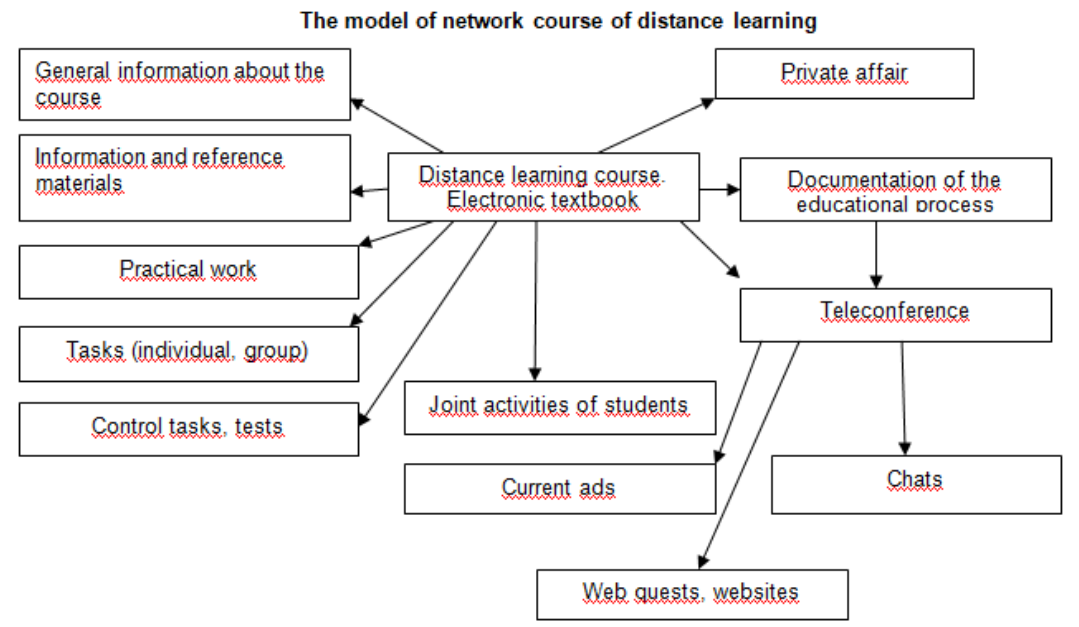

Fig.1. The model of network course of distance learning

It contains a separate article (Article 16) on the implementation of educational programs using e-learning and distance learning technologies. The concept of e-learning is considered in the named act as "the organization of educational activities ...", and not as "the organization of the educational process ...", the definition of the concept of distance learning technologies remained the same. The concepts of "distance education" and "distance learning" have not been consolidated in the said law again.

Researchers assess this fact differently, as the legislator's refusal to recognize distance education as a form of education, and distance learning as a form of education, and as an opportunity to do this, taking into account the new definition of the concept of "e-learning" in the Federal Law.

So, for example, I.V. Ginzburg and T.N. Troshkina believe that the form of education is a way of organizing the educational process and a special way of organizing educational activities [13].

V.I. Soldatkin believes that distance, as well as electronic, network, online, mobile, digital, etc. can only be training, teaching tools and methods, and its technologies. Education can be, taking into account the level of administrative regulation, open or closed, can be determined by the sectoral level. Refusing to give "distance learning" the status of a 
"form of learning" and introducing the concept of "e-learning", V.I. Soldatkin, the legislator has confused society: e-learning is the organization of activities with "the use of information and telecommunication networks", and distance educational technologies technologies with the "use of information and telecommunication networks." What is the difference between "e-learning" and "distance learning technologies"? The answer to this question, incorrectly formulated in the letter of the Ministry of Education and Science of the Russian Federation dated October 9, 2013 No. 06-735, to this question is that "elearning does not require interaction between students and teachers" V.I. Soldatkin rightly considers it as nonsense [14].

Approval by orders of the Ministry of Education and Science of the Russian Federation dated January 9, 2014 №2 (now invalidated) and dated August 23, 2017 №816 in relation to Art. 16 of the Federal Law of the new procedure for the application of e-learning, distance learning technologies by organizations carrying out educational activities in the implementation of educational programs also intensified the discussion.

In particular, the use of the new (not used in the Federal Law) concept of "online courses" in this Procedure reflects the development of e-learning, the transformation of its technologies into online learning technologies, which provide not only distance organization of educational activities, but also distance learning of educational programs.

\section{Conclusions}

In 2019-2020, the active use of e-learning and distance learning technologies in educational activities was facilitated by the adoption of measures to reduce the risks of the spread of a new coronavirus infection (COVID-19) in the Russian Federation and the establishment of some restrictions related to the implementation of educational activities.

As some authors justly point out, "now, in the conditions of informatization of society, more attention is paid to the process of teaching and upbringing" [15]. As part of the legal framework for the temporary procedure for the use of e-learning, distance learning technologies by organizations carrying out educational activities in the implementation of educational programs, many legal acts of various levels have been adopted - from general, departmental, local and local by-laws to Federal Law of 08.06.2020 № 164-FL, which amended the Federal Law "On Education in the Russian Federation" in terms of ensuring the continuity of the educational process in the context of the introduction of a high alert regime or an emergency on the entire territory of the Russian Federation or in its part.

Despite this, the functioning of the education system and the implementation of educational activities in the current conditions have shown that the legal regulation of the implementation of educational programs using e-learning and distance learning technologies has gaps and shortcomings.

Obviously, in the event of a threat and (or) the occurrence of individual emergencies, the introduction of a high alert or emergency situation throughout the territory of the Russian Federation or in its part, the right of organizations engaged in educational activities to use e-learning, distance educational technologies in the implementation of educational programs, as well as during the state final certification, which completes the development of basic professional educational programs, becomes their responsibility in terms of ensuring the continuity of the educational process.

The application of existing legislative norms to establish the procedure for the application of e-learning, distance learning technologies by organizations carrying out educational activities in the implementation of educational programs has shown the need to 
delineate the powers of the Ministry of Education of Russia and the Ministry of Education and Science of Russia on this issue.

The need for the massive use of distance educational technologies in the implementation of basic general education programs and basic educational programs of secondary vocational education sharply raised the question of the implementation of the guarantees established by law that these types of education are generally available and free of charge, etc.

All this requires, in an expeditious manner, to resolve the issues of the use and development of e-learning and distance learning technologies in the implementation of educational programs, including as measures for the formation of the information space of knowledge, both at the legislative, methodological and organizational levels.

\section{References}

1. K. Fischer, A college degree sorts job applicants, but employers wish it meant more, Chronicle of Higher Education, 4, (2013) http://chronicle.com/article/TheEmployment-

Mismatch/137625/?cid=wb\&utm_source $=$ wb\&utm_medium $=$ en\#id $=$ overview $\quad$ (Last accessed 20.05.2020)

2. L. V. Pushkareva, O. A. Galochkina, O. L. Bezgacheva, Current trends in the banking system of Russia, Espacios 40(4), 22 (2019)

3. O. Grokholskaya, Pedagogy, 7, 61-66 (2020)

4. I. S. Kusov, Experience and prospects of online education in Russia: collection of articles. articles of the All-Russian Scientific Conference, Sevastopol, Sevastopol: Branch of Moscow State University in Sevastopol, 11, 89, (2019)

5. O. Tikhonova, O. Chikhacheva, N. Grechushkina, Prospects for Science and Education, 1, 57-71 (2020)

6. G. Hwang, H. Chang, A Formative Assessment-Based Mobile Learning Approach to Improving the Learning Attitudes and Achievements of Students, Computers in Education, 56, 1023-1031, (2011)

7. M. Barber, K. Donnelly, S. Rizvi, Oceans of innovation: The Atlantic, the Pacific, global leadership and the future of education, IPPR (2012) http:// www.ippr.org/publication/55/9543/oceans-of-innovation-the-atlantic-thepacific-globalleadership-and-the-future-of-education (Last accessed 23.05.2020)

8. T. Menkhoff, M. Bengtsson, Engaging Students in Higher Education Through Mobile Learning: Lessons Learnt in a Chinese Entrepreneurship Course, Educational Research for Policy and Practice, 3, 225-242 (2012)

9. P. Newhouse, M. Cooper, J. Pagram, Bring Your Own Digital Device in Teacher Education, Journal of Digital Learning in Teacher Education, 31(2), 64-72 (2015)

10. B. R. Stockwell, M. S. Stockwell, M. Cennamo, E. Jiang, Blended Learning Improves Science Education, Cell Press, 162(5), 933- 936 (2015)

11. C. Stephen, Ludwig Higher Learning: Lessons from an Online Advocate, Educational Studies Moscow, 4, 167-187 (2018) DOI: 10.17323/1814-9545-2018-4-167-187

12. R. Stein, Supporting Online Initiatives: From MOOCs to For-Credit Offerings, Educational Studies Moscow, 4, 188-198 (2018) DOI: 10.17323/1814-9545-2018-4$188-198$ 
13. I. Ginzburg, T. Troshkina, Reforms and Law, 2, 50-56 (2013)

14. V. Soldatkin, Cloud of science, 2, 214-239 (2018)

15. R. DeVol, I. L. Shen, A. Bedroussian, N. Zhang, A matter of degrees: The effect of educational attainment on regional economic prosperity. Santa Monica: Milken Institute (2013)

http://www.milkeninstitute.org/publications/publications.taf? function=detail\&ID $=3880$ $\underline{1395 \& \text { cat }=\text { resrep }}$ (Last accessed 13.07.2020) 